\title{
Valorization of agroindustry waste for the elaboration of fishburgers
}

\author{
Valorização de resíduos agroindustriais para elaboração de fishburgers \\ Valorización de residuos agroindustriales para la elaboración de hamburguesas de pescado
}

\begin{abstract}
Waste production derived from agroindustry (bark, bagasse and seeds) has been increasing in Brazil. The cultivation of cashew to produce chestnuts and products obtained from cashew peduncle has generated a large amount of residue. Therefore, the objective of this study was to elaborate Nile tilapia fishburger with addition of cashew residue flour $(\mathrm{CRF})$ and evaluate its microbiological and physicochemical characteristics. Three formulations $\mathrm{F}_{0}, \mathrm{~F}_{1}$ and $\mathrm{F}_{2}(0 \%, 5 \%$ and $10 \% \mathrm{CRF}$, respectively) were elaborated as a substitute for mechanically separated meat (MSM) from Nile tilapia. The results of the microbiological analyzes of CRF and fishburgers were satisfactory, according to standards established by the Brazilian legislation. Fishburger formulations showed low lipid and high protein content. The analysis of centesimal composition showed that there was no significant difference $(p \geq 0.05)$ between the formulations (except water content and carbohydrate). The results show the elaboration of new products based on the residues of agroindustry provides greater access of fish products to different social classes and waste valorization. CRF has been applied to fishburger formulations satisfactorily, helping to reduce the environmental impacts associated with the disposal of this agroindustrial waste.
\end{abstract}

Keywords: Fish products; Flour; Tropical fruits; Cashew residue; Valorization.

\section{Resumo}

A produção de resíduos derivados da agroindústria (casca, bagaço e sementes) vem aumentando no Brasil. O cultivo do caju para a produção de castanhas e produtos obtidos do pedúnculo do caju tem gerado uma grande quantidade de resíduos. Portanto, o objetivo deste estudo foi elaborar um fishburger de tilápia do Nilo com adição de farinha de resíduo de caju (FRC) e avaliar suas características microbiológicas e físico-químicas. Três formulações $\mathrm{F}_{0}, \mathrm{~F}_{1}$ e $\mathrm{F}_{2}(0 \%, 5 \%$ e $10 \%$ de FRC, respectivamente) foram elaboradas como substituto para a carne mecanicamente separada (CMS) de tilápia do Nilo. Os resultados das análises microbiológicas da FRC e dos fishburgers foram satisfatórios, de acordo com os padrões estabelecidos pela legislação brasileira. As formulações de fishburger apresentaram baixo teor de lipídios e alto teor proteico. A análise da composição centesimal mostrou que não houve diferença significativa $(p \geq 0,05)$ entre as formulações (exceto teor de água e carboidratos). Os resultados mostram que a elaboração de novos produtos a partir dos resíduos da agroindústria proporciona maior acesso aos produtos derivados de pescado às diferentes classes sociais e valorização dos resíduos. A FRC tem sido aplicada em formulações de fishburger de forma satisfatória, ajudando a reduzir os impactos ambientais associados ao descarte desses resíduos agroindustriais.

Palavras-chave: Derivados de pescado; Farinha; Frutas tropicais; Resíduo de caju; Valorização. 


\begin{abstract}
Resumen
La producción de residuos derivados de la agroindustria (corteza, bagazo y semillas) ha ido aumento en Brasil. El cultivo de anacardo para producir castañas y los productos obtenidos de su tallo ha generado una gran cantidad de residuos. Por lo tanto, el objetivo de este estudio fue preparar una hamburguesa de pescado con tilapia del Nilo con la adición de harina de residuo de anacardo (HRA) y evaluar sus características microbiológicas y físico-químicas. Tres formulaciones $\mathrm{F}_{0}, \mathrm{~F}_{1}$ y $\mathrm{F}_{2}(0 \%, 5 \%$ y $10 \%$ de $\mathrm{HRA}$, respectivamente) se desarrollaron como sustituto de la carne separada mecánicamente (CSM) de la tilapia del Nilo. Los resultados de los análisis microbiológicos de HRA y hamburguesas de pescado fueron satisfactorios, según los estándares establecidos por la legislación brasileña. Las formulaciones de hamburguesa de pescado tenían un bajo contenido de lípidos y un alto contenido de proteínas. El análisis de la composición centesimal mostró que no hubo diferencia significativa $(\mathrm{p} \geq 0,05)$ entre las formulaciones (excepto el contenido de agua y carbohidratos). Los resultados muestran que la elaboración de nuevos productos basados en los residuos agroindustriales ofrece un mayor acceso a los productos de pescado a las diferentes clases sociales y la valorización de los residuos. La HRA se ha aplicado satisfactoriamente a las formulaciones de hamburguesas de pescado, ayudando a reducir los impactos ambientales asociados con la disposición de estos residuos agroindustriales.

Palabras clave: Productos de pescado; Harina; Frutas tropicales; Desperdicio de anacardo; Apreciación.
\end{abstract}

\title{
1. Introduction
}

Agribusiness is a prominent sector in the Brazilian economy. This has caused an increase in waste production mainly from the disposal of shells, bagasse and seeds. The recovery of these wastes provides the development of the bio-economy and the reduction of negative environmental impacts (Satari \& Karimi, 2018).

Cashew is a tropical fruit with high technological and economic potential (Guedes-Oliveira et al., 2016; Andrade et al., 2015). Northeast Brazil is the largest cashew producing region in the country (Oliveira Silva et al., 2014). Various products that can be marketed from cashew, such as juices, cashew nuts, sweets, among others.

According to data from the Institute of Applied Economic Research - IPEA, 80,484 tonnes of cashew residues were generated in Brazil in 2009 (IPEA, 2012). Most of these residues are rich in sugars, fiber, vitamins, minerals and antioxidant compounds, with great nutritional value and can be a source of obtaining these nutrients (Abud \& Narain, 2009).

The use of residues in the preparation of flour has been considered a promising technology, as it is economically and environmentally viable, in addition to having numerous applications (Alcântara et al., 2012; Coelho \& Wosiacki, 2010; Storck et al., 2015; Assis et al., 2019; Resende \& Franca, 2019). Coelho \& Wosiacki (2010) evaluated apple pomace flour added in bakery products. The physical-chemical composition of apple pomace flour presented $43 \%$ of fibers on a dry basis. The authors concluded that apple pomace flour may be a potential alternative source of dietary fibers in bakery products. Storck et al. (2015) evaluated the microbiological quality of residues flours from the processing of acerola, orange, grape and apple juices, and obtained satisfactory results. Pinho (2009) used cashew residue to elaborate beef hamburgers, proving to be a viable option, when compared to conventional beef hamburgers.

Fish products such as nuggets and fishburgers have been considered as an attractive food to consumers due their nutritional value and practicality (Mitterer-Daltoé et al., 2014; Amalia et al., 2016). These products allow the use of filleting and secondary parts of fish carcass, parts that would previously be discarded.

Mechanically separated meat (MSM) from fish is defined by Codex Alimentarius as a product obtained from a single species, or mixture of fish species with similar sensory characteristics, subjected to a process of mechanical separation from the edible part, resulting in skeletal muscle particles free of viscera, bones and skin (FAO, 1994). The chemical stability of fish MSM is related to lipid oxidation, mainly due to the action of atmospheric oxygen on unsaturated fatty acids present in fish, which can be oxidized even during the freezing storage period (Costa, 2017)

Seafood processing waste generally ranges from $20 \%$ to $60 \%$ of the initial raw material, with an average of 20 million tonnes worldwide (Suresh \& Prabhu, 2013). Waste of fish and seafood consists mainly (27\% of fish) of offal, heads and tails collected by gutting, cutting and filling processes (Plazzotta \& Manzocco, 2019). The utilization of filleting wastes from silver 
catfish in the formulation of fishburgers was evaluated by Bochi et al. (2008). The study showed that filleting wastes can replace up to $50 \%$ of fish fillets, without changes in sensory acceptance and improved nutritional value and cooking characteristics.

The use of food waste in the elaboration of other products can give these functional characteristics, since they are rich in many nutrients (Matias et al., 2005; Franceschinis et al., 2018). Thus, the industry has a cleaner production technology, less impact on the environment, and the ability to produce foods of high nutritional value (Sette et al., 2020). Consumers will benefit from the production of these foods as they may have nutritionally rich and lower cost products (Reetz et al., 2015).

In this context, the elaboration of new fish products can be considered as an alternative for the valorization of agribusiness residues. The present work aims to incorporate flour obtained from cashew residue as substitute of Tilapia MSM for fishburger production, evaluating its composition and nutritional value.

\section{Material and Methods}

The research was developed following a quantitative descriptive methodology, according to Pereira et al. (2018). The preparation of the product and the physical-chemical and microbiological analyzes were carried out at the Federal Institute of Education, Science and Technology of the State of Ceará, Limoeiro do Norte, from August / 2017 to July / 2018.

\subsection{Obtaining Raw Material and Ingredients}

Nile tilapia MSM and residues from the cashew pulping process were obtained from industries located in the Jaguaribe Valley region of Ceará State, Brazil. Other ingredients used in the preparation of fishburger formulations were purchased from local market in the city of Limoeiro do Norte-CE, Brazil.

\subsection{Preparation of cashew residue flour-CRF}

The CRF was obtained based on the methodology of Abud \& Narain (2009). The cashew residues were sent to the Fruit and Vegetable Processing Pilot Plant of the Federal Institute of Education Science and Technology of Ceara. The material was deposited in stainless steel trays and taken to a greenhouse with forced air circulation at $55{ }^{\circ} \mathrm{C}$, remaining for 24 hours. Subsequently, the dried residues were crushed in an industrial blender and sieved until the powder was properly sized (20 mesh). The flour was stored in sterile plastic containers and wrapped with aluminum foil to preserve its nutritional characteristics and stored at room temperature $\left(25^{\circ} \mathrm{C}\right)$.

\subsection{CRF analysis procedure}

Microbiological parameters were analyzed as recommended by Resolution RDC No 12 ANVISA - Agência Nacional de Vigilância Sanitária (Brasil, 2001). Salmonella sp analysis and thermotolerant coliform count followed the methodologies proposed by Silva et al. (2017)

CRF physicochemical characterization was obtained by determining $\mathrm{pH}$, total acidity, soluble solids (SS), vitamin C and the soluble solids/total acidity ratio. All analyzes were performed in triplicate, according to methodologies described by AOAC (2005). The determination of the proximate composition, lipid, water content, total protein (Kjeldahl method), crude fiber; ash and carbohydrates were performed in triplicate, according to method of AOAC (2005).

\subsection{Fishburger preparation and processing}

Three fishburger formulations were elaborated according Table 1. Control formulation $\left(\mathrm{F}_{0}\right)$ did not receive addition of $\mathrm{CRF}$ and $\mathrm{F}_{1}$ e $\mathrm{F}_{2}$ formulations received the addition of $5 \%$ and $10 \%$ of the flour as a substitute for Tilapia MSM, respectively. 
Research, Society and Development, v. 10, n. 3, e40010313395, 2021

(CC BY 4.0) | ISSN 2525-3409 | DOI: http://dx.doi.org/10.33448/rsd-v10i3.13395

Table 1 - Fishburger formulations from Nile tilapia MSM added cashew residue flour.

\begin{tabular}{lccc}
\hline \multirow{2}{*}{ Ingredients $(\boldsymbol{\%})$} & \multicolumn{2}{c}{ Formulation } \\
\cline { 2 - 4 } & $\mathbf{F}_{\mathbf{0}}$ & $\mathbf{F}_{\mathbf{1}}$ & $\mathbf{F}_{\mathbf{2}}$ \\
\hline MSM from Nile tilapia & 96.0 & 91.0 & 86.0 \\
Cashew residue flour-CRF & 0.0 & 5.0 & 10.0 \\
Salt & 2.5 & 2.5 & 2.5 \\
Dehydrated Garlic & 0.5 & 0.5 & 0.5 \\
Black pepper & 0.5 & 0.5 & 0.5 \\
Sugar & 0.3 & 0.3 & 0.3 \\
Monosodium glutamate & 0.2 & 0.2 & 0.2 \\
\hline
\end{tabular}

$\mathrm{F}_{0}=96 \%$ MSM, 0\% CRF; $\mathrm{F}_{1}=91 \%$ MSM, 5\% CRF; $\mathrm{F}_{2}=86 \%$ MSM, 10\% CRF. Source: Authors.

Initially, tilapia MSM were unfreeze at refrigeration temperature $\left(4{ }^{\circ} \mathrm{C}\right)$. Then the ingredients were weighed and mixed in a cutter until a homogeneous paste was obtained. Portions of approximately $80 \mathrm{~g}$ of meat dough were individually molded into hamburger patties and individually packed in plastic wrap and frozen at $-18{ }^{\circ} \mathrm{C}$ (Figure 1).

Figure 1 - The flowchart of fishburgers processing.

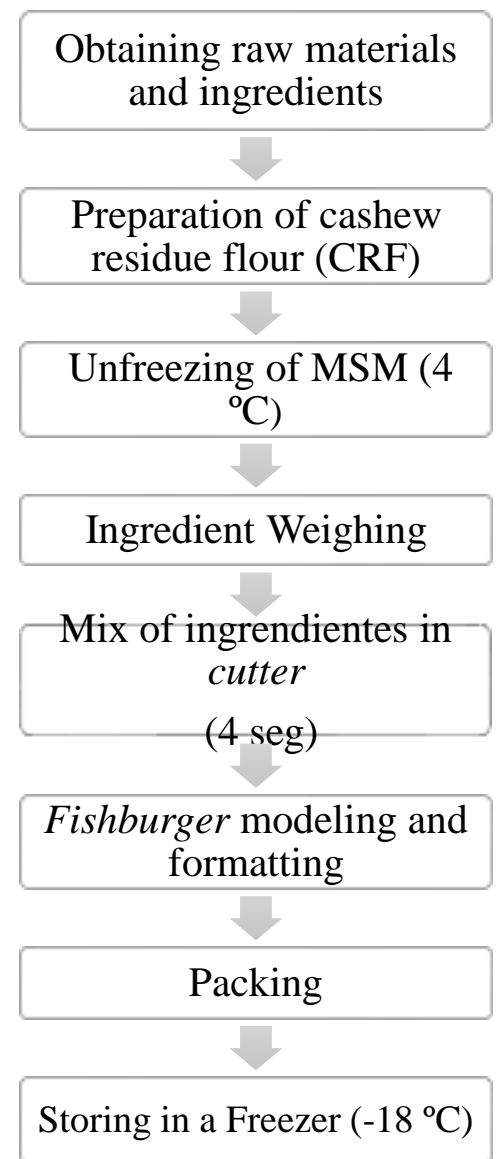

Source: Authors. 


\subsection{Fishburger microbiological analysis and proximate composition}

Microbiological analyzes were performed on all fishburger formulations as recommended by ANVISA (RDC No. 12) for fish derivatives including Samonella sp research, thermotolerant coliform counts and coagulase positive Staphylococcus (Brasil, 2001). Counts of mesophilic aerobic microorganisms and mold and yeast counts were also performed. All analyzes will follow the methodologies proposed by Silva et al. (2017).

Proximate composition analyzes were performed in fishburger formulations to determine the water content, lipids, total protein (Kjeldahl method), crude fiber, ashes, and carbohydrates. The methodologies used were those described by AOAC (2005).

Data were analyzed by variance (ANOVA) followed by Tukey test at 5\% significance. The software used was Statistica 10 program (Statsoft, 2011).

\section{Results and Discussion}

\subsection{CRF analysis}

Initially, CRF characterization was performed to evaluate microbiological and physicochemical parameters. Figure 2 shows the CRF obtained in this study. The results of the analyzes and the limits established for flour by Brazilian law are shown in Table 2.

Figure 2 - Flour obtained from cashew peduncle residue.

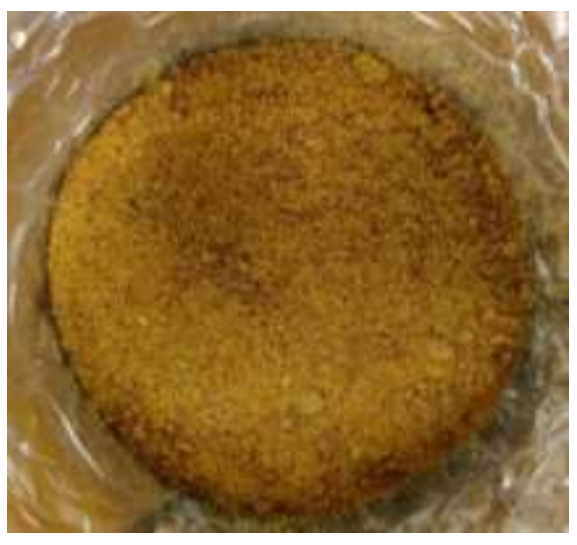

Source: Authors.

According to RDC $12 / 2001$ - ANVISA, the maximum values allowed for this type of food are: coliforms at $45^{\circ} \mathrm{C} / \mathrm{g} \leq 10^{2}$ MPN $/ g$, and absence of Salmonella sp. in $25 \mathrm{~g}$ of sample, and must also have absence of Escherichia coli (Brasil, 2001). The samples presented acceptable microbiological parameters, as shown in Table 2. These satisfactory results are related to the origin of the cashew peduncle residue that was used to prepare the flour.

Cashew is a naturally acidic fruit however changes can occur with its processing. The average $\mathrm{pH}$ value of the $\mathrm{CRF}$ was 4.4, considered in the acid range $(\mathrm{pH}<7)$ as shown in Table 2. Acid $\mathrm{pH}$ restricts the growth of microorganisms, agreeing with the satisfactory result for the microbiological standards verified in this study. The acidity value of fruits is related to its maturation stage. The total acidity analysis of the CRF presented a value of $1.53 \mathrm{~g} / 100 \mathrm{~g}$. Similar to the results obtained by Uchoa et al. (2008) and Muniz (2017). 
Research, Society and Development, v. 10, n. 3, e40010313395, 2021

(CC BY 4.0) | ISSN 2525-3409 | DOI: http://dx.doi.org/10.33448/rsd-v10i3.13395

Table 2 - Microbiological and physicochemical analyzes, proximate composition of CRF of the present study, criteria of Brazilian law and comparative results with other authors.

\begin{tabular}{|c|c|c|c|c|c|c|c|c|c|c|}
\hline \multirow[t]{2}{*}{ Parameter } & \multicolumn{9}{|c|}{ Results } & \multirow[t]{2}{*}{ Legislation } \\
\hline & $\begin{array}{l}\text { Present } \\
\text { study }\end{array}$ & $\begin{array}{l}\text { Storck et } \\
\text { al. }(2015)\end{array}$ & $\begin{array}{c}\text { Coelho \& } \\
\text { Wosiacki } \\
(2010) \\
\end{array}$ & $\begin{array}{l}\text { Uchoa } \\
(2008)\end{array}$ & $\begin{array}{l}\text { Pinho } \\
(2009)\end{array}$ & $\begin{array}{l}\text { Alcântara } \\
\text { (2012) }\end{array}$ & $\begin{array}{r}\text { Muniz } \\
\text { (2017) }\end{array}$ & $\begin{array}{l}\text { Andrade et } \\
\text { al. (2015) }\end{array}$ & $\begin{array}{c}\text { Guedes- } \\
\text { Oliveira et } \\
\text { al. (2016) }\end{array}$ & \\
\hline \multicolumn{11}{|l|}{ Microbiological } \\
\hline $\begin{array}{l}\text { Thermotolerant coliforms } \\
\text { (MPN/g) }\end{array}$ & $<3.00$ & $<3.00$ & $<3.00$ & - & - & - & - & - & - & $<1.00 \times 10^{2 *}$ \\
\hline Escherichia coli & Absence & Absence & Absence & - & - & - & - & - & - & Absence* \\
\hline Salmonella sp. & Absence & Absence & Absence & - & - & - & - & - & - & Absence* \\
\hline Physicochemical & & & & & - & - & - & - & - & \\
\hline $\mathrm{pH}$ & $4.40 \pm 0.05$ & - & - & 4.52 & 3.48 & 4.15 & 4.15 & 4.30 & 4.70 & - \\
\hline $\begin{array}{l}\text { Total acidity ( } \mathrm{g} \text { citric } \\
\text { acid/100 g) }\end{array}$ & $1.53 \pm 0.08$ & - & - & 1.38 & 2.61 & - & 1.23 & - & 0.69 & - \\
\hline Soluble solids $\left({ }^{\circ} \mathrm{Brix}\right)$ & $87.10 \pm 1.81$ & - & - & 40.48 & - & 36.67 & - & - & - & - \\
\hline $\begin{array}{l}\text { Vitamin C (mg ascorbic } \\
\text { acid/100 g) }\end{array}$ & $78.32 \pm 5.41$ & - & - & 34.72 & 9.32 & - & - & 78.50 & - & - \\
\hline soluble solids/total acidity & $56.88 \pm 2.24$ & - & - & 40.48 & - & - & - & - & - & - \\
\hline \multicolumn{11}{|l|}{ Proximate composition } \\
\hline Water content $\%$ & $12.15 \pm 1.18$ & - & - & 6.99 & 6.80 & 14.73 & 15.74 & 6.82 & 9.25 & $<15.00 *$ \\
\hline Lipids \% & $0.86 \pm 0.02$ & - & - & 3.03 & 1.07 & - & & 5.43 & 1.72 & - \\
\hline Total protein $\%$ & $4.79 \pm 1.38$ & - & - & 1.16 & 10.56 & - & 1.58 & 9.65 & 10.09 & - \\
\hline Crude fiber $\%$ & $19.62 \pm 11.80$ & - & - & 9.92 & 53.71 & - & - & - & 76.20 & - \\
\hline Ash \% & $2.21 \pm 0.04$ & - & - & 1.78 & 1.09 & 2.07 & 2.04 & 1.42 & 0.74 & - \\
\hline Carbohydrates $\%$ & $59.09 \pm 11.10$ & - & - & 36.55 & 9.86 & - & - & 76.68 & 2.24 & - \\
\hline
\end{tabular}

*Brasil (2001). **Brasil (2005b). MPN-Most Probable Numbers. Source: Authors. 
The analysis of soluble solids (SS) of the CRF showed an average value of $87.1^{\circ}$ Brix. The SS content may be associated with the type of cashew used in the production of the flour.

The vitamin C content is an important parameter of food quality, as it varies according to the conditions of cultivation, storage and processing (Pinho, 2009). Due to its characteristics such as high solubility in water and susceptibility to chemical degradation by oxidation, the level of ascorbic acid can change during food processing. The concentration of vitamin $\mathrm{C}$ found in the CRF of was $78.32 \mathrm{mg}$ of ascorbic acid/100 g. The Recommended Daily Intake (RDI) for adults by the National Academies of Sciences, Engineering, and Medicine (2019) is $75 \mathrm{mg} / \mathrm{d}$ for men and $60 \mathrm{mg} / \mathrm{d}$ for women. In Brazil ANVISA establishes an RDI of $45 \mathrm{mg} / \mathrm{d}$ for adults and $35 \mathrm{mg} / \mathrm{d}$ for children (Brasil, 2005a). Thus, CRF can be considered an important source of vitamin $\mathrm{C}$ reaching the recommended daily intake.

Regarding the centesimal composition, it was observed that the water content of the CRF obtained an average of $12.15 \%$ (Table 2). RDC 263/2005 ANVISA establishes a maximum humidity of 15.0\% (g/100 g) for flours, cereal starch and bran, and therefore the analyzed CRF is within the standards (Brasil, 2005b).

An average percentage of $0.86 \%$ was verified for the lipid content of the flour in this study, an approximate value obtained by Pinho (2009) (Table 2). The percentage of protein in the flour analyzed was $4.79 \%$. Protein content may vary according to various factors, such as crop, variety and harvest time.

The flour analyzed showed a crude fiber content of $19.62 \%$. The high fiber value verified in this study, suggests that the CRF can be used in other products, such as bakery, meat, among others widely consumed by the population. The average value of the ash analysis obtained for the CRF was $2.21 \%$. These levels may be associated with a higher concentration of minerals present in the analyzed residues, after the pulp extraction and drying process.

A high carbohydrate content was obtained in this study, with an average value of $59.09 \%$, which is related to the high concentration of SS previously presented in the CRF. Fruits in general, contain high sugar content, particularly fructose and glucose, also present in cashew (Andrade et al., 2015)

\subsection{Fishburger formulation analysis}

The Figure 3 presents Nile tilapia MSM fishburger formulations with added CRF $\left(\mathrm{F}_{0}, \mathrm{~F}_{1}\right.$ and $\left.\mathrm{F}_{2}\right)$. The results of the microbiological and physical chemical characterization of the fishburgers are shown in Table 3.

Figure 3 - Nile tilapia MSM fishburger formulations with added CRF.

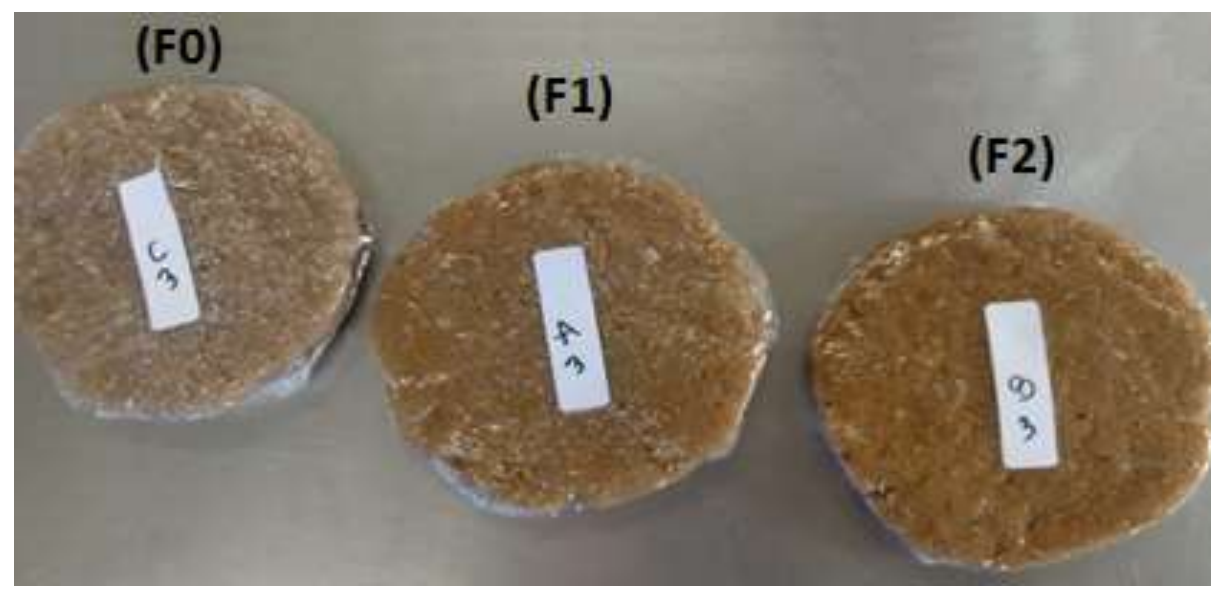

$\mathrm{F}_{0}=96 \%$ MSM, $0 \%$ CRF; $\mathrm{F}_{1}=91 \%$ MSM, 5\% CRF; $\mathrm{F}_{2}=86 \%$ MSM, 10\% CRF. Source: Authors 
Table 3 - Characterization of Nile tilapia MSM fishburgers added CRF.

\begin{tabular}{|c|c|c|c|c|}
\hline Parameter & $\mathbf{F}_{\mathbf{0}}$ & $\mathbf{F}_{1}$ & $\mathbf{F}_{2}$ & Legislation \\
\hline \multicolumn{5}{|l|}{ Microbiological } \\
\hline Thermotolerant coliforms (MPN/g) & $<3.00$ & $<3.00$ & $<3.00$ & $10^{3 *}$ \\
\hline Salmonella sp. & Absence & Absence & Absence & Absence in $25 \mathrm{~g} *$ \\
\hline coagulase positive Staphylococcus (CFU/g) & Absence & Absence & Absence & $10^{3 *}$ \\
\hline Mold and yeast (CFU/g) & Absence & Absence & Absence & - \\
\hline Mesophilic Aerobics (CFU/g) & $2.00 \times 10^{3}$ & $1.00 \times 10^{3}$ & $1.50 \times 10^{3}$ & - \\
\hline \multicolumn{5}{|l|}{ Proximate composition** } \\
\hline Water contente $\%$ & $77.79 \pm 0.54^{\mathrm{a}}$ & $74.32 \pm 0.51^{\mathrm{b}}$ & $71.23 \pm 0.23^{\mathrm{c}}$ & - \\
\hline Lipids $\%$ & $0.96 \pm 0.29^{\mathrm{a}}$ & $1.10 \pm 0.11^{\mathrm{a}}$ & $0.84 \pm 0.15^{\mathrm{a}}$ & - \\
\hline Total protein $\%$ & $16.22 \pm 0.78^{\mathrm{a}}$ & $15.59 \pm 1.47^{\mathrm{a}}$ & $14.97 \pm 0.54^{\mathrm{a}}$ & - \\
\hline Crude fiber $\%$ & $0.32 \pm 0.22^{\mathrm{a}}$ & $0.53 \pm 0.10^{\mathrm{a}}$ & $0.59 \pm 0.12^{\mathrm{a}}$ & - \\
\hline Ash \% & $3.13 \pm 0.49^{\mathrm{a}}$ & $3.37 \pm 0.56^{\mathrm{a}}$ & $3.38 \pm 0.65^{\mathrm{a}}$ & - \\
\hline Carbohydrates $\%$ & $1.58 \pm 1.04^{\mathrm{c}}$ & $5.09 \pm 1.53^{\mathrm{b}}$ & $8.99 \pm 0.70^{\mathrm{a}}$ & - \\
\hline
\end{tabular}

$\left(\mathrm{F}_{0}=96 \% \mathrm{MSM}, 0 \% \mathrm{CRF} ; \mathrm{F}_{1}=91 \% \mathrm{MSM}, 5 \% \mathrm{CRF} ; \mathrm{F}_{2}=86 \% \mathrm{MSM}, 10 \% \mathrm{CRF}\right)$. *Brasil (2001).**Averages followed by the same letter in an analysis do not differ significantly ( $\mathrm{p} \geq 0.05)$ MPN-Most Probable Numbers. CFU- Colony Forming Units. Source: Authors.

The analysis of all formulations showed low thermotolerant coliform counts, absence of Salmonella sp. in 25 grams of sample, coagulase positive Staphylococcus count and mold and yeast. These results guarantee the quality control carried out in the preparation of Nile Tilapia MSM fishburgers with the addition of CRF, confirming that they are suitable for human consumption, in accordance with current Brazilian legislation (Table 3) (Brasil, 2001). Similar results were found in other research with fish products (Costa, 2017; Marengoni et al., 2009; Pinto, 2017). Microbiological analysis of Tilapia hamburger, performed by Costa (2017), presented similar results, but obtained Staphylococcus counts (<100 CFU/g).

The data on the approximate composition of the three Nile tilapia MSM fishburger formulations with CRF are shown in Table 3. The analysis of the three formulations $\left(\mathrm{F}_{0}, \mathrm{~F}_{1}\right.$ and $\left.\mathrm{F}_{2}\right)$ showed a water content greater than $70 \%$, showing a significant difference between the formulations at $5 \%$ probability $(\mathrm{p}<0.05)$. The data indicate that by increasing the amount of CRF in the formulations $\left(\mathrm{F}_{0}=0 \% \mathrm{CRF} ; \mathrm{F}_{1}=5 \% \mathrm{CRF} ; \mathrm{F}_{2}=10 \% \mathrm{CRF}\right)$, the moisture value decreases. The reduction in the water content of the product $\left(\mathrm{F}_{1}\right.$ e $\left.\mathrm{F}_{2}\right)$ can contribute to a delay in bacterial growth, which is considered advantageous, as it results in greater durability of the fishburger.

The lipid content varied between 0.84 to $1.10 \%$, with no significant difference between the formulations ( $\mathrm{p} \geq 0.05$ ). The protein content was high, with values between 14.97 and $16.22 \%(\mathrm{p} \geq 0.05)$, characteristic of fish derivatives.

The percentages of crude fiber (0.32-0.59\%) and ash (3.13-3.38\%) were higher in formulations containing addition of $\mathrm{CRF}\left(\mathrm{F}_{1}=5 \% \mathrm{CRF} ; \mathrm{F}_{2}=10 \% \mathrm{CRF}\right)$, with no significant difference between formulations $(\mathrm{p} \geq 0.05)$.

For the determination of carbohydrates, there is a significant difference between the three formulations $(p<0.05)$, with the highest value observed in $F_{2}(8.99 \pm 0.70)$. These results are also related to the amount of CRF added, as the flour is inserted, the total carbohydrate content increases with each formulation.

The centesimal composition data indicate that there was no difference $(p \geq 0.05)$ between the formulations (except water content and carbohydrate). This shows that the flour can be used as a substitute for fish in the indicated proportions, not causing significant changes in its composition, being satisfactorily applicable and generating a valorization of cashew waste. 
The $\mathrm{F}_{2}$ formulation with $10 \% \mathrm{CRF}$ had a higher content of crude fiber, ash and carbohydrates, being considered the best formulation from the nutritional point of view. The elaborated fishburger showed quality comparable to other fish products (Marengoni et al., 2009; Costa, 2017; Pinto, 2017)

Thus, the residue flour was applied to fishburger formulations helping to reduce waste and environmental hazards. The food industry, when producing the fishburger, would have a reduction in the costs of the raw material (MSM of tilapia), since this is replaced by the CRF. The acquisition of the waste will not bring high costs, because many times this waste is disposed in the environment by the agro-industries, being able to be easily acquired for a very low cost. However, the company must have the equipment for the preparation of the flour, or already acquire the residue in the form of powder, facilitating the process.

\section{Conclusion}

Physico-chemical and microbiological characterization of agro-industrial residue for valorization in fish derivatives proved to be viable. The CRF presented satisfactory microbiological standards and centesimal composition in accordance with Brazilian legislation. The results of microbiological analyzes of fishburger demonstrated satisfactory quality, adequate processing, meeting the standards required by legislation. Nile tilapia MSM fishburger formulations with CRF addition showed low lipid content and high protein content within what is expected for fish derivatives. The F2 formulation with $10 \% \mathrm{CRF}$ had a higher content of crude fiber, ash and carbohydrates, being considered the best formulation from the nutritional point of view. Therefore, with the elaboration of new products based on waste, it can have a wider public, due to its low cost and satisfactory nutritional quality. CRF can be used satisfactorily as a substitute for fish in the preparation of fishburgers, generating a valorization of cashew waste.

For future studies, the development of new formulations is suggested, increasing the percentage of substitution of the ingredients of the cashew residue and MSM of the Nile tilapia. In addition, it is recommended to evaluate the acceptance, as well as, the identification of the bioactive compounds and the antioxidant activity of the CRF, increasing the valorization of the cashew pulp residue and the final product elaborated.

\section{Acknowledgments}

The authors gratefully the FUNCAP, CAPES and CNPq for financial support of this search.

\section{References}

Abud, A. K. S., \& Narain, N. (2009). Incorporação da farinha de resíduo do processo de polpa de fruta em biscoitos: uma alternativa de combate ao desperdício. Brazilian Journal of Food Technology, 12(4), 257-265. 10.4260/BJFT2009800900020

Alcântara, S. R., Sousa, C. A. B., Almeida, F. A. C., \& Gomes, J. P. (2012). Caracterização físico-química das farinhas do pedúnculo do caju e da casca do maracujá. Revista Brasileira de Produtos Agroindustriais, 14, 473-478.

Amalia, U., Darmanto, Y. S., \& Rianingsih, L. (2016). Chemical Characteristics of Fish Nugget with Mangrove Fruit Flour Substitutio. Aquatic Procedia, 7, 265-270. 10.1016/j.aqpro.2016.07.037

Andrade, R. A. M. S., Maciel, M. I. S., Santos, A. M. P., \& Melo, E. A. (2015). Optimization of the extraction process of polyphenols from cashew apple agroindustrial residues. Food Science and Technology, 35(2), 354-360. 10.1590/1678-457X.6585

Aoac (2005). Official methods of Analysis of the Association of Official Analytical Chemistry. Gaithersburg: AOAC International.

Assis, R. Q., Andrade, K. L., Batista, L. E. G., de Oliveira Rios, A., Dias, D. R., Ndiaye, E. A., \& de Souza, É. C. (2019). Characterization of mutamba (Guazuma ulmifolia LAM.) fruit flour and development of bread. Biocatalysis and agricultural biotechnology, 19, 101120. 10.1016/j.bcab.2019.101120

Brasil (2001). Agência Nacional de Vigilância Sanitária - ANVISA 2001. Resolução RDC nº 12, de 02 de janeiro de 2001, aprova o Regulamento Técnico sobre padrões microbiológicos para alimentos. Diário Oficial [da] República Federativa do Brasil, Brasília. 
Research, Society and Development, v. 10, n. 3, e40010313395, 2021 (CC BY 4.0) | ISSN 2525-3409 | DOI: http://dx.doi.org/10.33448/rsd-v10i3.13395

Brasil (2005a). Agência Nacional de Vigilância Sanitária - ANVISA 2005. Resolução RDC no 269, de 22 de setembro de 2005, aprova o Regulamento Técnico sobre a ingestão diária recomendada $(I D R)$ de proteína, vitaminas e minerais. Diário Oficial [da] República Federativa do Brasil, Brasília.

Brasil (2005b). Agência Nacional de Vigilância Sanitária - ANVISA 2005. Resolução RDC n²63, de 22 de setembro de 2005, aprova o Regulamento Técnico para produtos de cereais, amidos, farinhas e farelos. Diário Oficial [da] República Federativa do Brasil, Brasília.

Bochi, V. C., Weber, J., Ribeiro, C. P., Victório, A. D. M., \& Emanuelli, T. (2008). Fishburgers with silver catfish (Rhamdia quelen) filleting residue. Bioresource Technology, 99(18), 8844-8849. 10.1016/j.biortech.2008.04.075

Coelho, L. M., \& Wosiacki, G. (2010). Avaliação sensorial de produtos panificados com adição de farinha de bagaço de maçã. Food Science and Technology, 30(3), 582-588. 10.1590/S0101-20612010000300003

Costa, D. P. S. D. (2017). Desenvolvimento de hambúrguer com carne mecanicamente separada de carcaça e de refile de tilápia: caracterização microbiológica, físico-química e sensorial. 93 f. Tese Doutorado em Ciência e Tecnologia de Alimentos.

de Oliveira Silva, R., de Castro, R. C., Milhome, M. A. L., \& do Nascimento, R. F. (2014). Liquid chromatography-electrospray ionization-tandem mass spectrometry method for determination of twenty multi-class pesticide residues in cashew. LWT-Food Science and Technology, 59(1), 21-25. 10.1016/j.lwt.2014.05.035

FAO (1994). Food and Agriculture Organization of the United Nations. Draft revised standard for quick frozen blocks of fish fillet, minced fish flesh and mixtures of fillets and minced fish flesh (Appendix IV). Codex Alimentarius Commission. www.fao.org/input/download/standards/111/CXS_165epdf

Franceschinis, L., Sette, P., Salvatori, D., \& Schebor, C. (2018). Valorization of postharvest sweet cherry discard for the development of dehydrated fruit ingredients: compositional, physical, and mechanical properties. Journal of the Science of Food and Agriculture, 98(14), 5450-5458. 10.1002/jsfa.9089

Guedes-Oliveira, J. M., Salgado, R. L., Costa-Lima, B. R., Guedes-Oliveira, J., \& Conte-Junior, C. A. (2016). Washed cashew apple fiber (Anacardium occidentale L.) as fat replacer in chicken patties. LWT-Food Science and Technology, 71, 268-273. 10.1016/j.1wt.2016.04.005

IPEA (2012). Instituto de Pesquisa Econômica Aplicada. 20 Boletim Radar - Tecnologia, Produção e Comércio Exterior. Brasília.

Marengoni, N. G., dos Santos Pozza, M. S., Braga, G. C., Lazzeri, D. B., Castilha, L. D., Bueno, G. W., \& Polese, C. (2009). Caracterização microbiológica, sensorial e centesimal de fishburgers de carne de tilápia mecanicamente separada. Revista Brasileira de Saúde e Produção Animal, 10(1), 168-176.

Matias, M. F. O., Oliveira, E. L., \& Magalhães, M. M. A. (2005). Use of fibrous obtained from the cashew (Anacardium occidentale L.) and guava (Psidium guayava) fruits for enrichment of food products. Brazilian Archives of Biology and Technology, 48(Especial), 143-150. 10.1590/S1516-89132005000400018

Mélo, H. M. G., Galvão, S. M. R., Silva, J. G., Maciel, M. I. S., Moreira, R. T., Andrade, S. A. C., \& Mendes, E. S. (2014). Qualidade do fishburger de carne mecanicamente separada de tilápia do Nilo adicionado de fibra de trigo e óleo de milho. Ars Veterinária, 30(1), 23-31. 10.15361/2175-0106.2014v30n1p23-31

Mitterer-Daltoé, M. L., Queiroz, M. I., Fiszman, S., \& Varela, P. (2014). Are fish products healthy? Eye tracking as a new food technology tool for a better understanding of consumer perception. LWT-Food Science and Technology, 55(2), 459-465. 10.1016/j.1wt.2013.10.013

Muniz, C. E. D. S. (2017). Elaboração de barras de cereais utilizando resíduos agroindustriais de goiaba e caju enriquecidos proteicamente por via microbiana. 71 f. Dissertação Mestrado em Engenharia Química.

National Academies of Sciences, Engineering, and medicine. (2019). http://nationalacademies.org/hmd/Activities/Nutrition/SummaryDRIs/DRI-Tables.aspx

Pereira, A. S., Shitsuka, D. M., Parreira, F. J., \& Shitsuka, R. (2018). Metodologia da pesquisa científica. UFSM. https://repositorio.ufsm.br/bitstream/handle/1/15824/Lic_Computacao_MetodologiaPesquisaCientifica.pdf?sequence=1.

Pinho, L. X. (2009). Aproveitamento do pedúnculo de caju (Anacardium occidentale L.) para alimentação humana. 85 f. Dissertação Mestrado em Ciência e Tecnologia de Alimentos.

Pinto, B. V. V. (2017). Elaboração de fishburger com resíduos da filetagem da tilápia do Nilo (Oreochromis niloticus, Linnaeus 1758) adicionado de transglutaminase. 96 f. Dissertação Mestrado em Ciências.

Plazzotta, S., \& Manzocco, L. (2019). Food waste valorization. Saving Food,1, 279-313.

Reetz, E. R., Kist, B. B., Santos, C. E., Carvalho, C., \& Drum, M. (2015). Anuário brasileiro da fruticultura. Santa Cruz do Sul: Editora Gazeta Santa Cruz. 104 p. DOI:10.1016/b978-0-12-815357-4.00010-9

Resende, L. M., \& Franca, A. S. (2019). Flours Based on Exotic Fruits and Their Processing Residues-Features and Potential Applications to Health and Disease Prevention. In Flour and Breads and their Fortification in Health and Disease Prevention (pp. 387-401). Academic Press. 10.1016/B978-0-12-814639-2.000307

Satari, B., \& Karimi, K. (2018). Citrus processing wastes: Environmental impacts, recent advances, and future perspectives in total valorization. Resources, Conservation and Recycling, 129, 153-167. 10.1016/j.resconrec.2017.10.032

Sette, P., Fernandez, A., Soria, J., Rodriguez, R., Salvatori, D., \& Mazza, G. (2020). Integral valorization of fruit waste from wine and cider industries. Journal of Cleaner Production, 242, 118486. 10.1016/j.jclepro.2019.118486

Silva, N., Junqueira, V. C. A., Silveira, N. F. A., Taniwaki, M. H., Gomes, R. A. R., \& Okazaki, M. M. (2017). Manual de métodos de análise microbiológica de alimentos e água. (5a ed.), Blucher. 
Research, Society and Development, v. 10, n. 3, e40010313395, 2021 (CC BY 4.0) | ISSN 2525-3409 | DOI: http://dx.doi.org/10.33448/rsd-v10i3.13395

Statsoft. (2011). Statistica for Windows - Computer program manual, version 10.0. Tulsa: Statsoft Inc.

Storck, C. R., Basso, C., Favarin, F. R., \& Rodrigues, A. C. (2015). Qualidade microbiológica e composição de farinhas de resíduos da produção de suco de frutas em diferentes granulometrias. Brazilian Journal of Food Technology, 18(4), 277-284. 10.1590/1981-6723.1615

Suresh, P. V., \& Prabhu, G. N. (2013). Seafood. In: Chandrasekaran, M. (Ed.) - Valorization of food processing by-products (p. 685-736). CRC Press.

Uchoa, A. M. A., da Costa, J. M. C., Maia, G. A., Silva, E. M. C., Carvalho, A. D. F. F. U., \& Meira, T. R. (2008). Parâmetros físico-químicos, teor de fibra bruta e alimentar de pós alimentícios obtidos de resíduos de frutas tropicais. Segurança Alimentar e Nutricional, 15(2), 58-65. 10.20396/san.v15i2.18 